\title{
Weeds Cause Losses in Field Crops through Allelopathy
}

\author{
Ali ZOHAIB*, Tasawer ABBAS, Tahira TABASSUM \\ University of Agriculture,Department of Agronomy, Faisalabad,Pakistan; alizohaib208@gmail.com (*corresponding author); tagondaluaf@gmail.com; \\ tabira2561@gmail.com
}

\begin{abstract}
A large number of weeds are known to be associated with crops and causing economic losses. Weeds interfere with crops through competition and allelopathy. They produce secondary metabolites known as allelochemicals, which belong to numerous chemical classes such as phenolics, alkaloids, fatty acids, indoles, terpens etc. However, phenolics are the predominant class of allelochemicals. The allelochemicals release from weed plants takes place through leaf leachates, decomposition of plant residues, volatilization and root exudates. Weeds leave huge quantities of their residues in field and affect the associated, as well as succeeding crops, in various cropping systems. Liberation of allelochemicals from weeds affects the germination, stand establishment, growth, yield and physiology of crop plants. They cause substantial reduction in germination and growth of the crop plants by altering various physiological processes such as enzyme activity, protein synthesis, photosynthesis, respiration, cell division and enlargement, which ultimately leads to a significant reduction in crop yield. In crux, allelopathic weeds represent a potential threat for crop plants and cause economic losses.
\end{abstract}

Keywords: allelochemicals, crop physiology, crop yield, germination and growth, weed allelopathy, phenolics, secondary metabolites

\section{Introduction}

Weeds are associated with many crops and are a major threat to crop production in many cropping systems. Losses due to weeds have been estimated to be even more than those caused by insect pests and diseases. It has been observed that weeds may cause a reduction up to $25-30 \%$ in the yield of wheat (Chaudhary et al., 2008; Marwat et al., 2008), 35-40\% reduction in rice yield (Oerke and Dehne, 2004), 35-80\% reduction in maize (Dangwal et al., 2010) and 20-40\% reduction in sugarcane yield (Ibrahim et al., 1984; Khan et al., 2004), depending upon weed density, types of weeds, duration of competition, management practices and weather conditions. Weeds cause a reduction in the growth and yield of crops by interfering with different metabolic processes (Hajizadeh and Mirshekari, 2011). The interference of weeds with crops may be the consequence of competition and/or allelopathy.

Allelopathy is regarded as any process whereby secondary metabolites produced by plants, microorganisms, viruses and fungi influence the growth and development of agricultural and biological systems, including positive and negative effects (Torres et al., 1996). The ability of various plant species to induce allelopathic impacts on plants in their surroundings has been documented since ancient times. The most primitive writings on allelopathy are accredited to the Theophrastus (300 BC) who detected the detrimental effect of cabbage over the growth of a vine and proposed that such effects were occurred by odours from cabbage plants (Willis, 1985). The term allelopathy was coined by a German plant physiologist named Molisch (1937), deriving from the Greek word "allelon" which means of "each other", while "pathos" means "to suffer". Allelochemicals are secondary metabolites which are liberated from plants and affect the germination and growth of recipient plants (Kruse et al., 2000; Asaduzzaman et al., 2010). Allelochemicals are released through volatilization, root exudation, residues decomposition and leaching from leaf litter, and they act upon by various modes of actions. Seed germination and plant growth is interrupted by the disturbance of a variety of physiological functions occurring within plant bodies. The plant functions of prime importance which are affected by allelochemicals include respiration, photosynthesis, cell division and enlargement, metabolic activities, protein synthesis and enzyme actions (Lin et al., 2004).

A large number of allelopathic weeds have been documented in the literature as they affect crop plants right from their emergence till maturity and cause considerable economic losses. Weeds allelopathy has been found responsible for perturbation of emergence and stand establishment, growth, yield and physiology of crop plants.

To best of our knowledge, limited review is available in specialized literature that emphasized the injurious allelopathic effects of weeds on crops. Within the present review, an attempt has been made to elucidate the weeds containing potentially active allelochemicals, weeds allelochemicals mode of release and their harmful effects on germination, stand establishment, crop growth and development, crop yield and alterations in crop physiological processes. 
48

\section{Allelochemicals in weeds}

A large number of allelochemicals, which affect the recipient plants in various ways, have been found and identified in weed plants. These allelochemicals have been classified into different groups depending upon their properties. Phenolics, terpenes, fatty acids and indoles are the most commonly occurring allelochemicals in plants (Noguchi, 2008). Similar to other plant species, weeds produce a large number of allelochemicals that influence the crop plants in their vicinity. Sambucus nigra contains at least 24 allelochemicals which belong to lignans, cyanogenins, phenolic glycosides and flavonoids. These compounds were used in a bioassay study to examine their effects on lettuce, onion and radish. Cyanogenins showed inhibitory effect, while lignans stimulated the plants' growth (D'Abrosca et al., 2001). Leonurus sibiricus root exudates contains phenolics such as caffeic acid. Mandal (2001) observed that it has inhibitory effect on different crops. Conyza canadensis water extract was observed to contain vanillic acid, gallic acid, syringic acid and cathecol, as determined by chromatographic analyses. Germination and seedling growth of okra, bitter gourd, tomato and onion was reduced by water extract of dry plants of Cyperus rotundus (Ameena and Sansamma, 2002). They reported that the phenolic acids which were present in water extracts of dry plant organs were the cause of inhibition of germination and seedling growth of test crops. Sasikumar et al. (2002) reported inhibitory effect of Parthenium hysterophorus plant organs containing phenolic compounds (caffeic acid, p-coumaric acid, p-hydroxy benzoic acid and vanillic acid) on cowpea, blackgram, green gram, horse gram and pigeon pea. The mixture of these phenolic acids, as well as their role as individual compounds, inhibited the germination and vigor index of all tested crops. Shaukat et al. (2003) noted that $C$. canadensis imposed inhibitory effect on radish, tomato, corn, wheat, mung bean and bulrush millet. Addition of shoots for decomposition in the sandy loam soil also inhibited the germination and growth of bulrush millet. Rahman (2005) reported that the aqueous extracts from inflorescences, stem and leaves of $P$. bysterophorus containing parthenin, caffeic acid and p-coumaric acid resulted in a reduction of the germination percent, low growth of radical and plumule, as well as low dry weight of Cassia tora seedlings. Shao et al. (2005) determined three sesquiterpenoids named deoxymikanolide, dihydromikanolide and 2,3-epoxy-1-hydroxy-4,9germacradiene-12,8:15,6-diolide and found that they exhibit allelopathic activity on the germination and growth of Acacia mangium, Lactuca sativa, Pinus massoniana and Eucalyptus robusta. Hegazy and Farrag (2007) analyzed the water, methanol and oil extracts of Chenopodium ambrosioides and found that it contained flavonoids, alkaloids, terpenoids and volatile oils. Water extract of $C$. ambrosioides was observed to be inhibitory to the percent germination of Beta vulgaris, Lycopersicon esculentum, Sonchus oleraceus and $M$. indicus. The methanol and oil extracts were found inhibitorier than water extract. Khanh et al. (2008) found that Echinocloa crusgalli infested soil contained 18 compounds belonging to terpenes, derivatives of cinnamic acid and ferulic acid, long chain fatty acids and steroids, and thus affected rice.

Table 1 summarizes many classic and novel candidates for allelochemicals produced by some important weeds in world.

Allelopathic weeds produce a large number of allelochemicals belonging to diverse chemical classes, depending upon their characteristics. In general, the allelochemicals released from the weeds belong mostly to the phenolics, terpenoids, alkaloids, fatty acids, indols, lignans, cyanogenins, phenolic glycosides, flavonoids and coumarins. Furthermore, a large number of novel allelochemicals have also been discovered from several weeds.

\section{Allelochemicals release modes}

Allelochemicals can liberate from plants through different modes, depending upon species and environmental conditions. Their release takes place through leaching from the leaves or other plant parts, decomposition of plants residues, volatilization and root exudation (Bertin et al., 2003).

\section{Leachates}

Water soluble allelochemicals such as phenolics, alkaloids and terpenoids are released from different plant organs in the form of leachates and affect the germination and growth of accepter plants (Das et al., 2012). Plant leachates suppress the germination of seed and vegetative propagules, as well as radical and plumule growth (Casado, 1995). Leaf leachates of Hyptis suaveolens investigated for their effects on the germination and biochemical attributes of Parthenium hysterophorus revealed that leachates exert inhibitory effects on $P$. hysterophorus seedlings (Kapoor, 2012). Jinhu et al. (2012) reported that Eupatorium adenophorum leaf leachates exerted inhibitory as well as promoting effects on the membrane permeability, germination and dry matter accumulation of Amaranthus retroflexus and $C$. glaucum seedlings. Higher concentrations substantially reduced the biosynthesis of chlorophyll content and enzyme activity, while increasing the malondialdehyde (MDA) accumulation. However, lower concentrations of leachates showed promoting allelopathic effect. Echinochloa colona leaf leachates significantly reduced the germination and growth of rice seedlings in different media viz. soil, filter paper and soil plus activated charcoal (Swain et al., 2012).

\section{Decomposition}

Large amount of allelochemicals add up in the soil by decomposition of plant residues and affect the target plants on exposure (Matloob et al., 2010). Allelochemicals are released directly or by the action of microbes from plants residues. In field conditions, the release of allelochemicals mostly occurs from residues decomposing (Singh et al., 2001). Allelochemicals accumulate in the soil through discharge by decomposition of plant residues and cause soil sickness. The accumulation of allelochemicals in soil leads to a reduction in seed germination and plant growth, decreased primary roots and increased secondary roots, chlorosis, poor nutrient absorption, maturation delayed and reproduction failure (Narwal et al., 2005). Residues of Chromolaena odorata 
incorporated in soil showed inhibition of $L$. esculentum seedling germination and growth characteristics at all the concentrations of residues incorporated in soil (Enyi, 2001). Soil amended with residues of $P$. hysterophorus was tested by Singh et al. (2005) and it was observed that incorporation of residues at the rate of $40 \mathrm{~g}$ per $\mathrm{kg}$ of soil decreased the size and biomass of $B$. oleracea, $B$. campestris and $B$. rapa upon decomposition. These results were credited to the phenolics released into the soil with water from decomposing residues of $P$. hysterophorus. The influence of Lantana camara, $A$. conyzoides and $E$. adenophorum residues addition in soil at $5 \%$ and $10 \%$ concentrations, was found inhibitory on emergence and shoot growth of wheat, rice and maize. The effect was proportional to the concentration of the incorporated residues (Katoch et al., 2012).

\section{Volatilization}

The release of volatile allelochemicals from plants and the impact upon receptor plants takes place by direct absorption in vapours form from atmosphere or through absorption along with dew or rain water. Camphor, camphene, dipentene, cineole, alpha and beta pinene are the most common volatile compounds that are released from plants (White et al., 1989). Obaid and Qasem (2005) reported that volatiles extracted from shoots of Convolvulus arvensis, A. gracilis, Portulaca oleracea and $L$. serriola caused a reduction in the growth of cabbage, cucumber, squash, onion, pepper, tomato and carrot. However, the volatiles from $C$. arvensis and $L$. serriola caused mostly inhibitory effect. Volatiles from shoots of Cardaria draba and Salvia syriaca caused inhibitory effects on cabbage, carrot, cucumber, squash, onion, pepper and tomato. Germination and seedling growth characteristics of several test crops were reported to be affected by volatiles (Qasem, 2001).

Table 1. Classic and novel candidates for allelochemicals found in some important weeds considered worldwide

\begin{tabular}{|c|c|c|}
\hline Weeds & Allelochemicals & Reference \\
\hline Alternantheraphiloxeroides & 4-Hydroxy-3-methoxybenzoic acid, m-coumaric acid, p-coumaric acid & Mehmood et al.(2014) \\
\hline Alternantherasessilis & Chlorogenic acid, ferulic acid, gallic acid, vanilic acid & Mehmood et al.(2014) \\
\hline Avenafatua & $\begin{array}{l}\text { Vanillic acid, scopoletin, ellagic acid, chlorogenic acid, caffeic acid, p-coumaric acid, ferulic acid, p- } \\
\text { hydroxy-benzoic acid }\end{array}$ & $\begin{array}{l}\text { Schumacher et al.(1983); Qureshi et al. } \\
\text { (1987) }\end{array}$ \\
\hline Bothriochloa laguroides & E,E-farnesol, hexadecane, n-dodecane, 1-tetradecene & Scrivanti (2010) \\
\hline Chenopodium album & Chlorogenic acid & Malliket al.(1994) \\
\hline Chenopodium ambrosioides & Limonene, $\alpha$-terpinene, ascaridole (1-methyl-4(1-methylethyl)-2-3-dioxabicyclo[2.2.2] oct-5-ene) & Hegazy and Farrag (2007) \\
\hline Chenopodium murale & Benzoic acid, p-coumaric acid, ferulic acid and vanillic acid & Batish et al. (2007a) \\
\hline Cirsium arvense & Vanillic acid, caffeic acid, ferulic acid, p-coumaric acid, chlorogenic acid, p-hydroxybenzoic acid & Hussain etal.(1987) \\
\hline Convolvulus arvensis & $\begin{array}{l}\text { p-Hydroxybenzoic acid, p- coumaric acid, pyrogallic acid, protocatechuic acid, resorcinol, chlorogenic } \\
\text { acid, caffeic acid, syringic acid, ferulic acid, salicylic acid, cinnamic acid }\end{array}$ & Hegab and Ghareib (2010) \\
\hline Conyzastricta & Chlorogenic acid, ferulic acid, m-coumaric acid & Abbaset al. (2014) \\
\hline Cyperusesculentus & Ferulic acid, p-hydroxybenzoic acid, syringic acid, vanillic acid, p-coumaric acid & Tameset al.(1973) \\
\hline Cyperusrotundus & Catechol tannins, sesquiterpenes & Komai and Ueki (1975) \\
\hline Echinochloa crusgalli & m-Coumaric acid, p-coumaric acid, vanilic acid & Abbasetal.(2014) \\
\hline Eclipta alba & Vanillic acid, ferulic acid, benzoic acid, p-coumaric acid & Gulzar andSiddiqui (2015) \\
\hline Eichhorniacrassipes & Isocyanatoethyl acetate, propane amide, 2-2-dimethyl cyclopentane & Jin etal. $(2003)$ \\
\hline Lathyrusaphaca & Gallic acid, caffeic acid, syringic acid, m-coumaric acid & Zohaib et al.(2014) \\
\hline Medicagopolymorpha & 4-Hydroxy-3-methoxybenzoic acid, p-coumaric acid, vanilic acid, m-coumaric acid & Zohaib et al. (2014) \\
\hline Melilotusindica & Caffeic acid, ferulic acid, chlorogenic acid & Zohaib etal.(2014) \\
\hline Parthenium hysterophorus & $\begin{array}{l}\text { Parthenin, caffeic acid, coronopilin acid, vanillic acid, chlorogenic acid, ferulic acid, anisic acid, saponins, } \\
\text { tannins, cardiac glycosides, myrcene, ocimene, } \beta \text {-pinene }\end{array}$ & Tanveer et al.(2015) \\
\hline Polygonum barbatum & Caffeic acid, chlorogenic acid, m-coumaric acid, p-coumaric acid & Abbasetal.(2014) \\
\hline Rutagraveolens & $\begin{array}{l}\text { a-Pinene, camphene, b-pinene, heptane-2-one, p-cymene, limonene, 1,8-cineole, n-octanol, } \\
\text { terpinolene, valeric acid, non-2-ene, nonan-2-one, linalool, phenylethyl alcohol, nonan-2-ol, octanoic } \\
\text { acid, methyl salicylate, decan-2-one, decan-2-ol, octyl acetate, undecan-2-one, undecan-2-ol, dodec-2- } \\
\text { ene, tridecane, decyl-2-acetate, dodecan-2-one, tridecan-2-one, } \alpha \text {-copaene, } \beta \text {-caryophyllene, } \alpha \text { - } \\
\text { humulene, } \Delta \text {-cadinene, hexadecane, } \alpha \text {-eudesmol, pentadecan-2-one, heptadecane, pentadecanol, 1- } \\
\text { hexadecanol, xanthotoxin, furocoumarins, flavonoids }\end{array}$ & Aliotta et al.(1999); Feoa et al.(2002) \\
\hline Sorghum halepense & Chlorogenic acid, phenolic compounds, p-hydroxybenzeldehyde, p-coumaric acid & Abdul-Wahab and Rice(1967) \\
\hline Terminalia catappa & $\begin{array}{l}\text { 2-Pentadecanone, syringic acid, vanillic acid, ferulic acid, palmitic acid, p-coumaric acid, stearic acid, } \\
\text { 3,3,4tri-O-methyl ellagic acid, } \beta \text {-sitosterol-3-O- } \beta \text {-D-glucoside }\end{array}$ & Baratelli et al.(2012) \\
\hline Trigonellapolycerata & 4-Hydroxy-3-methoxybenzoic acid, syringic acid, m-coumaric acid & Zohaib etal.(2014) \\
\hline Viciasativa & Ferulic acid,4hydroxy-3-methoxybenzoic acid, p-coumaric acid & Zohaib etal.(2014) \\
\hline Nigellasativa & $\begin{array}{l}\text { Thymoquinone, thymohydroquinone, } \\
\text { thymol, dithymoquinone, carvacrol, nigellidine, nigellicine, } \alpha \text {-hederin }\end{array}$ & $\begin{array}{l}\text { Randhawa and Al-Ghamdi (2002); } \\
\text { Gali-Muhtasib et al.(2006); Al-Saleh } e t \\
\text { al.(2006) }\end{array}$ \\
\hline Stauranthusperforates & $\begin{array}{l}\text { Pyranocoumarins [xanthyletin and 3-(10,10-dimethylallyl)-xanthyletin], furanocoumarins } \\
\text { [chalepensin, ammirin, chalepin and 20-isopropyl-psoralene], lignans [asarinin and fargesin], } \\
\text { sesquiterpene [4,5-epoxi-b-caryophyllene], alkamide [pellitorine] }\end{array}$ & Anaya et al. (2005) \\
\hline Stellerachamaejasme & $\begin{array}{l}\text { Neochamaejasmin B, mesoneochamaejasmin A, chamaejasmenin C, genkwanol A, daphnodorin B, } \\
\text { dihydrodaphnodorin B }\end{array}$ & Yan etal.(2014) \\
\hline Sphenodeazeylanica & Epi-zeylanoxide A,zeylanoxide A, zeylanoxide B, epi-zeylanoxide B & Hiraia et al. (2000) \\
\hline
\end{tabular}




\section{Root exudation}

Allelochemicals ooze out from the roots in the rhizosphere and affect the plants in their vicinity (Senarathne et al., 2010). Root exudates of Chenopodium murale in agar were found to reduce the wheat seedling growth. Nearly $44 \%$ and $32 \%$ decrease was noted in root and shoot length of wheat seedlings respectively, whereas seedlings' dry weight decreased up to $52 \%$ (Batish et al., 2007b). Cenchrus ciliaris and Bothriochloa pertusa root exudates were used for a bioassay study to examine their effects against Brassica campestris, L. sativa, Setaria italica and Pennisetum americanum. Lower concentrations were found to have stimulatory effect or no effect on the root and shoot growth of tested crops, while higher concentrations were proved inhibitory (Hussain et al., 2011). Evaluation of the effect of $A$. retroflexus root exudates on growth of Phaseolus vulgaris exhibited the inhibition of root and shoot growth of $P$. vulgaris upon exposure to exudates (Namdari et al., 2012).

In conclusion weeds liberate several types of allelochemicals through various modes such as leaching through plants in the form of leachates, decomposition of weeds residues, volatilization and root exudates, and affect plants in their vicinity.

\section{Allelopathic effects of weeds on field crops}

Weeds exert a diverse range of effects on field crops through the release of allelochemicals in their surroundings. Some of the potential impacts of allelopathic weeds on field crops are reviewed in the following sections.

\section{Germination and stand establishment}

Allelopathy imposes both detrimental as well as beneficial biochemical interactions among plants and microorganisms through the release of allelochemicals. Weeds release large amounts of allelochemicals in soil, which affect the germination and stand establishment of associated as well as succeeding crops. Phenolic compounds, lignans, cyanogenins, phenolic glycosides, sesquterpenoids and flavonoids released in soil from weed plants either through exudation, leachates and/or decomposition of residues inhibit or stimulate the germination and seedling vigour of crops (D’Abrosca et al., 2001; Yukiko et al., 2001; Shao et al., 2005). Phenolic compounds are the most important allelopathic substances that are involved in the biochemical interactions. Weeds produce large quantities of phenolics which are most actively participating in the allelopathic interactions involving both inhibitory and promoting effects on crop plants. Leachates and decomposing residues of weeds in soil add up water soluble phenolic compounds which lower the percent and rate of emergence as well as growth of crop plants (Zohaib et al., 2014; Abbas et al., 2015). Ferulic acid, p-coumaric acid, vanilic acid, caffeic acid, chlorogenic acid, gallic acid and 4hydroxy-3-methoxybenzoic acid are the most commonly occurring plant phenolic compounds and have been detected in many weed plants which inhibit the germination and decrease seedling vigour (Rodzynkiewicz et al., 2006; Muzaffar et al., 2012; Zohaib et al., 2014). The inhibition of germination by allelochemicals is the result of inhibition of respiration by interruption of respiratory enzymes and enzymes involved in oxidative pentose phosphate pathway (Muscolo et al., 2001).

Many studies have revealed the allelopathic effects of weeds on germination and crop stand establishment. Residues of leaves, stems, roots and whole plants of Polygonum bydropiper, $A$. spinosus, $C$. album, $C$. rotundus and Imperata cylindrica and their mixtures imposed an inhibitory effect on the emergence of maize seedlings. They delayed the seedling emergence and reduced the seedling vigour (Samad et al., 2008). Jabeen and Ahmed (2009) found that the residues of Asphodelus tenuifolius, Euphorbia birta and $F$. indica, mixed thoroughly in the soil at concentrations of $10 \mathrm{~g}, 25 \mathrm{~g}, 50 \mathrm{~g}$ and $100 \mathrm{~g}$ per $500 \mathrm{~g}$ of soil had retarding effects on emergence and seedling establishment of maize. Fresh and dry plant material of $P$. bysterophorus was composted in soil to check possible effects on the emergence and growth rate of lettuce seedlings. The results indicated inhibitory allelopathic effects on percent emergence, radical and plumule growth of lettuce seedlings. The inhibition by fresh biomass was stronger compared with the effect of dried biomass of weed (Wakjira et al., 2009). Soil infested with $E$. helioscopia residues was found to inhibit the emergence of chickpea, wheat and lentil. It was further revealed that emergence was substantially delayed by $E$. helioscopia allelochemicals that were accumulated in soil (Tanveer et al., 2010). Inhibitory effect of L. siribicus was perceived on Solanum melongena, Abelmoschus esculentus, $A$. tricolor and Cucumis sativus seedlings. Inhibition of germination was occurred by water extract, acetone extract and methanol extract of L. siribicus (Sayed et al., 2012). Calotropis procera allelopathic extract proved toxic to final germination, germination index and seedling establishment of wheat in different media including sand, blotter paper and soil along with soaking of wheat seeds in water extract of $C$. procera, at same concentration (Yasin et al., 2012). Calotropis procera allelopathy was also found toxic against eggplant, tomato and cucumber germination and seedling vigour (Ghasemi et al., 2012). Allelopathic water extracts of Plantago lanceolata, Anagallis arvensis, M. polymorpha, Phragmites australis, Ammi visnaga, Silybum marianum, Malcolmia africana, Emex spinosa, Calendula arvensis, Fumaria indica, C. arvense and Rumex crispus showed toxicity against maize, sunflower and wheat germination. Water extracts decreased the percent germination and germination index while exaggerated the time for germination. The sunflower was more prone to inhibition, while maize was more resistive. $R$. crispus was observed inhibitorier than all other weeds (Khan et al., 2012).

In crux, the allelochemicals, and even more commonly the phenolic compounds, that are released from weeds affect the germination and crop stand establishment through disruption of various vital processes such as respiration and activity of enzymes that are involved in the process of germination. They also affect the crop stand establishment through reduction of seedling vigour.

\section{Growth and development of crop plants}

Allelochemicals released from weeds exhibit a decrease in growth and development of crop plants through 
disruption of vital physiological processes. The reduction in plant growth and development comes from the inhibition of cell division and photosynthesis due to disruption of chlorophyll cells (Shao-Lin et al., 2004). A large number of allelochemicals such as ferulic acid, chlorogenic acid, caffeic acid, vanilic acid, 4-hydroxy-3-methoxybenzoic acid, pcoumaric acid and gallic acid have been observed to cause hindrance of plant growth (Rodzynkiewicz et al., 2006; Muzaffar et al., 2012). Weeds release a large quantity of allelochemicals in the soil and plant environment that is enough to exert damaging effects on crop plant growth. Alam and Shaikh (2007) carried out an experiment to examine the effect of leaf water extract of nettle leaf goosefoot alone, $\mathrm{NaCl}$ alone and combination of both on rice growth. All treatments reduced the shoot and root growth of rice. The most affected growth parameter was root length. Dry plant residues of Cassia angustifolia were incorporated into the soil as powder and mulch for checking its possible allelopathic effects on rice, maize, wheat and sorghum. It was found that all the attributes pertaining to plant growth viz. seedling length, dry weight and number of leaves of all the crops were retarded except wheat in which a promotion in growth was observed (Hussain et al., 2007). Phytotoxicity of Prosopsis juliflora extract was demonstrated at two concentration levels ( 5 and $10 \%$ ) against wheat seedlings. An inhibition of root growth of wheat was observed; the inhibitory effect was proportional to extract concentration (Siddiqui et al., 2009). In a different study, Cyperus rotundus, Commelina benghalensis, Prosopis juliflora and P. hysterophorus residues were augmented in soil and their impact was observed on growth of soybean, sorghum and groundnut at varying concentrations of residues $(5,10$ and $20 \mathrm{~g} / \mathrm{kg}$ soil). The results revealed that there was more growth inhibition of soybean than sorghum and groundnut. A substantial reduction in plant height, leaf area, stem and leaf weights were perceived in response to allelopathic weeds residues. Cyperus rotundus and C. benghalensis showed more inhibitory effect and the inhibition increased with an increase in concentration of weeds residues (Jalageri et al., 2010).

Determination of the effects of $C$. iria residues incorporated in soil on five varieties of rice namely MRQ74, MR84, MR211, MR220 and MR232 showed that there was significant reduction in plant height, root and shoot length, plant fresh weight of rice plants (Ismail and Siddique, 2011). Residues of Inula viscose leaves and flowers were mixed in soil at a concentration of $1.25 \mathrm{~g}$ and $2.5 \mathrm{~g}$ per $\mathrm{kg}$ and their impact was examined against radish and lettuce. There was considerable inhibitory effect of allelochemicals present in the residues of I. viscose on the emergence and growth of radish and lettuce. Shoot and root growth of both crops was inhibited. The effect was increased by increasing concentration of residues in soil (Omezzine et al., 2011). Studies were conducted by Hamidi and Ghadiri (2011) to assess the effect of root and shoot water extracts of wild barley on wheat with a result of reduction in shoot and root length, as well as the number of seminal roots of wheat plants. The inhibitory effects of root water extract were more significant at higher concentration. The most affected trait was root length in their study. Assessment of allelopathic effects of residues of Fimbristylis miliacea on growth of various varieties of rice was done at different concentrations including $0.5,1$ and $2 \%(\mathrm{w} / \mathrm{w})$. It was found that there was an inhibitory effect of weed debris on all the attributes of growth. There was a significant reduction in the seedling length and dry matter production by the application of weed residues (Ismail and Siddique, 2012). Johani et al. (2012) affirmed by a bioassay study that Malva parviflora and C. murale aqueous water extracts at 25, 50, 75 and 100 percent concentrations caused a negative effect on the growth of barley. It was noted that $C$. murale caused more retarding effect on plant height, leaf area, leaf fresh and dry weight, root dry weight, number of leaves and number of tillers of barley. However, the retarding effect of M. parviflora was observed only on leaf growth. More growth retarding effects were observed at higher concentrations. Sultana and Asaduzzaman (2012) found out the allelopathic effects of $S$. marianum fresh and hot water extracts on ryegrass and canola at various concentration levels. It was noted that higher concentrations of both fresh and hot water extracts were inhibitory to the root and shoot growth of test crops. Allelopathic effect of leaf water extract of Argemone mexicana was determined by Alagesaboopathi (2013) on sorghum seedlings at varying concentrations. A significant inhibitory effect was noted on growth of sorghum plants. The radical and plumule length was significantly reduced due to the effect of water extract of $A$. Mexicana, at higher extract concentrations.

In summary, a large number of allelochemicals liberated from the weeds are involved in the inhibition of vital physiological processes such as cell division, cell elongation and photosynthesis, which are essential for growth and development of crop plants. They inhibit the root and shoot growth, and lower the dry matter production.

\section{Crop yield}

Weeds causes yield reductions through weed-crop competition and allelopathy. However, in field conditions it is difficult to differentiate the cause of crop yield reduction, as to identify if this is caused by weeds' allelopathic interactions or due to weed-crop competition. Weeds are unwanted plants which compete with the associated crop plants for space, moisture, nutrients and light, and thus obstruct the growth, eventually decreasing the yield both qualitatively and quantitatively. Most of the studies have concentrated on the determination of yield losses due to competition and critical levels of weed-crop competition (Ali et al., 2015). Recently, the determination of yield losses due to weed-crop allelopathic interactions has been undermined. Therefore, scanty information is available regarding the assessment of yield losses due to weeds allelopathy.

Weeds suppress the crop stand establishment and plant growth through their allelopathic effect and cause a considerable reduction in crop yield. The decrease in yield may be due to the reduction in number of productive tillers per unit area, number of seeds per spike and decrease in the seed weight due to impairment of important physiological functions of plants. The crop yield is much more dependent on the number of fertile tillers per unit area than weeds are. 
52

Allelochemicals liberated from the weeds in crop vicinity affects the seed germination, seedling growth and stand establishment, ultimately leading to a reduced number of tillers per unit area. Further, weeds suppress the growth of crop plants rendering them to stress factors. The reproductive growth of crop plants is influenced by the vegetative growth of plants to a great extent and requires a good balance between vegetative and reproductive growth for a good yield. The allelopathic effects of weeds on crop stand establishment and plant growth has been discussed in previous sections, while the physiological processes that are impaired by weed allelopathic effects that are to be discussed hereby.

Some studies have enabled the scientists to know how the crop yield is impaired by weeds allopathic interactions. Potential allelopathic effect of wild barley residues that were deposited in the soil at different concentrations against vegetative and reproductive growth of wheat was assessed by Hamidi et al. (2008). No effect was found from the treatment with residues at lower concentrations. However, higher concentrations were found effective in reducing growth and yield of wheat. The decrease in yield was found to be due to lesser number of tillers per plant, while grain weight was affected by weed residues at higher concentration. Mohadesi $e t$ al. (2011) revealed that water extracts of barnyard grass, umbrella sedge, monochori alone and their combination lowered the rice yield. There was a reduction in growth of flag leaf and number of tillers, and also there was a decrease in days to panicle emergence and $50 \%$ flowering that may be the reasons behind lowered crop yield. Majeed et al. (2012) noticed a reduction in wheat yield by the effect of water extract of $C$. album at higher concentrations. They observed that growth and yield parameters of wheat were decreased by water extract at higher concentrations and increased at a lower concentration viz. $25 \%$. The reduction of yield was due to a decrease in the number of tillers per plant, number of grains per spike and grain weight by the influence of water extracts at higher concentrations as compared to untreated control and vice versa for lower concentration.

In conclusion, within field conditions is considered difficult to differentiate the cause of crop yield reduction whether it is attributable to allelopathy or competition. However, results of some studies have revealed that allelopathic weeds negatively affect the yield by influencing the crop stand establishment and reducing the number of productive tillers per unit area, as well as by decreased number of grains per spike and seed weight.

\section{Cropphysiology}

Allelochemicals are responsible for the modulation of physiological processes taking place within plants. These alterations may take place in the hormonal balance, protein synthesis, enzyme activity, photosynthesis, respiration etc. Weeds alter the pattern of growth and development of crop plants through changes in the physiological processes by releasing the allelochemicals within their vicinity. The allelopathic effect of Charlock (Sinapis arvensis) plant organs aqueous extracts at $0.5 \%$ and $1.5 \%$ concentrations against canola (Brassica napus) revealed that shoot extract inhibited the protein synthesis and Hill reaction. It reduced chlorophyll $a$ and total chlorophyll at $1.5 \%$ concentration.
Chlorophyll $b$ was reduced at $1.5 \%$ concentration of root extract. Shoot and root extracts of $S$. arvensis increased soluble carbohydrates, proline and decreased non-soluble carbohydrate contents in canola. Shoot and root extracts of $S$. arvensis at $1.5 \%$ concentration increased catalyzed oxidation of guaiacol (peroxidase activity) of canola (Haddadchi and Khorasani, 2006). Similarly, water extracts of $S$. nigrum and $P$. hysterophorus showed an increase in protein content in various varieties of soybean (Verma and Rao, 2006).

Total chlorophyll contents and the amount of proteins and carbohydrates of Cicer arientinum and Pisum sativum were reduced when both legume crops were grown in soil amended with 5, 10, 20 and $40 \mathrm{~g}$ residue $\mathrm{kg}^{-1}$ soil of $C$. murale (Batish et al., 2007a). Otusanya (2008) demonstrated that leachates of Tithonia diverifolia inhibited the photosynthetic pigments in Lycopersicon esculentum and Capsicum annum. Chlorophyll $b$ of $C$. annum was reduced by the action of allelochemicals that were present in leachates, while chlorophyll $b$ and total chlorophyll of $L$. esculentum was enhanced. Allelochemicals from $C$. arvensis methanol extract at various concentrations viz. $75 \mathrm{ppm}, 150 \mathrm{ppm}, 300 \mathrm{ppm}$ and $600 \mathrm{ppm}$ imposed a stimulatory allelopathic effect on the biosynthesis and accumulation of chlorophyll and protein contents, carbohydrates and phenolic compounds of wheat. Similarly, activity of antioxidant enzymes such as peroxidase (POD), catalase (CAT), super oxide dismutase (SOD) and phenol oxidase increased, while lipid peroxidation and $\mathrm{H}_{2} \mathrm{O}_{2}$ content in wheat plants decreased by the effect of allelochemicals at lower concentrations. Higher levels of chlorophyll and antioxidants were observed at $300 \mathrm{ppm}$ (Hegab and Ghareib, 2010). Hui et al. (2011) noted that plant material of garlic stalk upon decomposition exerted an inhibitory effect on antioxidants viz. SOD, POD and CAT of Chinese cabbage, tomato, lettuce, carrot, hot pepper and cucumber seedlings, while the MDA content increased upon decomposition. Water extracts of Cynodon dactylon and Ammania baccifera showed an inhibitory as well as stimulatory effect at different concentrations on the physiological and biochemical attributes of black gram. The stimulatory effect was observed at lower concentrations while higher concentrations were observed to cause inhibitory effect on photosynthetic pigments viz. chlorophyll $a, b$ and total chlorophyll, protein content, amino acids, sugars, starch and proline content (Kavitha and Arumugam, 2012).

In conclusion, allelochemicals disturb numerous essential physiological processes such as protein synthesis, enzyme activity, chlorophyll synthesis and maintenance, photosynthetic rate and respiration. Furthermore, it increases the production of reactive oxygen species and reduces the activity of antioxidant enzymes that leads to lipid peroxidation and results in imbalanced plant growth and development.

\section{Conclusions}

Weeds are a diverse group of plants that grow either in association along with crops or may grow in places where they are not required. When they occur in association with 
crops they cause economic losses through competition or by releasing allelochemicals, in the process known as allelopathy. Weeds produce a large number of allelochemicals belonging to different chemical classes, and liberate them through different metabolic processes such as leaching, decomposition of residues, volatilization and root exudation; their effects impair the germination, crop stand establishment, growth of crop plants and reduce yield. The allelochemicals released by weeds disrupt many physiological processes of crop plants and impact upon plant growth and development. In crux, the allelopathic effects of weeds are threats to qualitative and quantitative yields and their control is crucial for economic crop production.

\section{References}

Abbas T, Tanveer A, Khaliq A, Safdar ME, Nadeem MA (2014). Allelopathic effects of aquatic weeds on germination and seedling growth of wheat. Herbologia 14(2):22-36.

Abbas T, Nadeem MA, Tanveer A, Zohaib A (2015). Comparative influence of water soluble phenolics of warm climate aquatic weeds on weeds species composition and rice-wheat cropping system. Scientia Agriculture 10(3):145-150.

Abdul-Wahab AS, Rice EL (1967). Plant inhibition by Johnsongrass and its possible significance in old-field succession. Bulletin of the Torrey Botanical Club 94:486-497.

Alagesaboopathi C (2013). Allelopathic effect of different concentration of water extract of Argemone mexicana L. on seed germination and seedling growth of Sorghum bicolor (L.) Moench. Journal of Pharmacy and Biological Sciences 5(1):52-55.

Alam SM, Shereen A (2002). Effects of plant and weeds residues on the growth of rice. Pakistan Journal of Botany 34(2):139-143.

Alam SM, Shaikh AH (2007). Influence of leaf extract of nettle leaf goosefoot (Chenopodium murale L.) and $\mathrm{NaCl}$ salinity on germination and seedling growth of rice (Oryza sativa L.). Pakistan Journal of Botany 39(5):1695-1699.

Ali HH, Tanveer A, Naeem M, Jamil M, Iqbal M, Chadhar AR, Kashif MS (2015). Assessing the competitive ability of Rhynchosia capitata; an emerging summer weed in Asia. Planta Daninha 33(2):175-182.

Aliotta G, Cafiero G, Conti S, Corsaro MM, Oliva A (1999). Germination of radish (Raphanus sativus L.) seeds in presence of rue (Ruta graveolens L.) infusion: a cellular perspective. In Second World Congress on Allelopathy: Critical Analysis and Future Prospects. Lakehead University, Canada.

Al-Saleh IA, Billedo G, El-Doush II (2006). Levels of selenium, DL-atocopherol, DL-gtocopherol, all-trans-retinol, thymoquinone and thymol in different brands of Nigella sativa seeds. Journal of Food Composition and Analysis 19(2):2-3.

Ameena M, Sansamma G (2002). Allelopathic influence of purple nutsedge (Cyperus rotundus L.) on germination and growth of vegetables. Allelopathy Journal 10(2):147-151.

Anaya AL, Macías-Rubalcava M, Cruz-Ortega R, García-Santana C, Sánchez-Monterrubio PN, Hernández-Bautista BE, Mata R (2005). Allelochemicals from Stauranthus perforatus, a Rutaceous tree of the Yucatan Peninsula, Mexico. Phytochemistry 66(4):487-494.

Asaduzzaman M, Islam MM, Sultana S (2010). Allelopathy and allelochemicals in rice weed management. Bangladesh Research Publications Journal 4(1):1-14.

Baratelli TG, Gomes ACC, Wessjohann LA, Kuster RM, Simas NK (2012). Phytochemical and allelopathic studies of Terminalia catappa L. (Combretaceae). Biochemical Systematics and Ecology 41:119-125.

Batish DR, Lavanya K, Singh HP, Kohli RK (2007a). Phenolic allelochemicals released by Chenopodium murale affect the growth, nodulation and macromolecule content in chickpea and pea. Plant Growth Regulation 51(2):119-128.

Batish DR, Lavanya K, Singh HP, Kohli RK (2007b). Root-mediated allelopathic interference of nettle-leaved goosefoot (Chenopodium murale) on wheat (Triticum aestivum). Journal of Agronomy and Crop Science 193(1):37-44.

Bertin C, Yang X, Weston LA (2003). The role of root exudates and allelochemicals in the rhizosphere. Plant and Soil 256(1):67-83.

Casado CM (1995). Allelopathic effect of Lantana camara (Verbenaceae) on morning glory (Impomoea tricolor). Rhodora 97:264-274.

Chaudhary SU, Hussain M, Ali MA, Iqbal J (2008). Effect of weed competition period on yield and yield components of wheat. Journal of Agricultural Research 46(1):47-54.

D’Abrosca B, Greca MD, Fiorentino A, Monaco P, Previtera L, Simonet AM, Zarrelli A (2001). Potential allelochemicals from Sambucus nigra. Phytochemistry 58(7):1073-1081.

Dangwal RL, Singh A, Singh T, Sharma C (2010). Effect of weeds on the yield of wheat crop in Tehsil Nowshera. Journal of American Science 6(10):405-407.

Das CR, Mondal NK, Aditya P, Datta JK, Banerjee A, Das K (2012). Allelopathic potentialities of leachates of leaf litter of some selected tree species on gram seeds under laboratory conditions. Asian Journal of Experimental Biological Sciences 3(1):59-65.

Enyi JO (2001). Allelopathic effects of Chromolaena odorata L. (R. M. King and Robinson (Awolowo Plant')) toxin on tomatoes (Lycopersicum esculentum Mill). Journal of Applied Sciences and Environmental Management 5(1):69-73.

Feo VD, Simone FD, Senatore F (2002). Potential allelochemicals from the essential oil of Ruta graveolens. Phytochemistry 61(5):573-578.

Gali-Muhtasib H, Roessner A, Schneider-Stock R (2006). Thymoquinone, a promising anti-cancer drug from natural sources. International Journal of Biochemistry and Cell Biology 38(8):1249-1253.

Ghasemi S, Ghasemi M, Moradi N, Shamili AM (2012). Effect of Calotropis procera leaf extract on seed germination of some plants. Journal of Ornamental and Horticultural Plants 2(1):27-32.

Gulzar A, Siddiqui MB (2015). Root-mediated allelopathic interference of bhringraj (Eclipta alba L.) Hassk. on peanut (Arachis hypogaea) and mung bean (Vigna radiata). Applied Soil Ecology 87:72-80.

Haddadchi G, Khorasani FM (2006). Allelopathic effects of aqueous 
54

extracts of Sinapis arvensis on growth and related physiological and biochemical responses of Brassica napus. Journal of Society for Underwater Technology 32(1):23-28.

Hajizadeh R, Mirshekari B (2011). Interference of wild oat (Avena fatua) with wheat cultivars. Journal of Food, Agriculture and Environment 9(3-4):398-399.

Hamidi D, Ghadiri H (2011). Winter wheat cultivars responses to allelopathic potential of wild barley (Hordeum spontaneum) extracts. Journal of Plant Breeding and Crop Science 3(14):391395.

Hamidi R, Mazaheri D, Rahimian H, Alizadeh HM, Ghadiri H, Zeinali $\mathrm{H}$ (2008). Phytotoxicity effects of soil amended residues of wild barley (Hordeum spontaneum Koch) on growth and yield of wheat (Triticum aestivum L.). Desert 13(1):1-7.

Hegab MM, Ghareib HR (2010). Methanol extracts potential of field bindweed (Convolvulus arvensis L.) for wheat growth enhancement. International Journal of Botany 6(3):334-342.

Hegazy AK, Farrag HF (2007). Allelopathic potential of Chenopodium ambrosioides on germination and seedling growth of some cultivated and weed plants. Global Journal of Biotechnology and Biochemistry 2(1):1-9.

Hiraia N, Sakashita S, Sano T, Inoue T, Ohigashia H, Premasthira C,...Fujii Y (2000). Allelochemicals of the tropical weed Sphenoclea zeylanica. Phytochemistry 55(2):131-140.

Hossain MK, Alam MN (2010). Allelopathic effects of Lantana camara leaf extract on germination and growth behavior of some agricultural and forest crops in Bangladesh. Pakistan Journal of Weed Science Research 16(2):217-226.

Hui CZ, Hui WC, Mei XX, Khan MA (2011). Allelopathic effects of decomposing garlic stalk on some vegetable crops. African Journal of Biotechnology 10(69):15514-15520.

Hussain F, Ilahi I, Malik SA, Dasti AA, Ahmad B (2011). Allelopathic effects of rain leachates and root exudates of Cenchrus ciliaris $\mathrm{L}$. and Bothriochloa pertusa (L.) A. Camus. Pakistan Journal of Botany 43(1):341-350.

Hussain F, Khan TW, Hussain A (1987). Allelopathic effects of Cirsium arvense (L.) Scop. in modern trends of plant science research in Pakistan. Proceedings of the Third National Conference of Plant Scientists, Department of Botany. Peshawar, University of Peshawar pp 24-28.

Hussain S, Siddiqui SU, Khalid S, Jamal A, Qayyum A, Ahmad Z (2007). Allelopathic potential of senna (Cassia angustifolia Vahl.) on germination and seedling characters of some major cereal crops and their associated grassy weeds. Pakistan Journal of Botany 39(4):1145-1153.

Ibrahim ASS (1984). Weed competition and control in sugarcane. Weed Research 24(4):227-271.

Ismail BS, Siddique AB (2012). Allelopathic inhibition by Fimbristylis miliacea on the growth of the rice plants. Advances in Environmental Biology 6:2423-2427.

Ismail BS, Siddique MAB (2011). The inhibitory effect of grasshopper's cyperus (Cyperus iria L.) on the seedling growth of five Malaysian rice varieties. Tropical Life Sciences Research
22(1):81-89.

Jabeen N, Ahmed M (2009). Possible allelopathic effects of three different weeds on germination and growth of maize (Zea mays) cultivars. Pakistan Journal of Botany 41(4):1677-1683.

Jalageri BR, Channappagoudar BB, Surwenshi A, Nakul HT (2010). Allelopathic effects of prominent weed species on cereals, pulses and oilseed crops. Research Journal of Agricultural Sciences 1:107-112.

Jin ZH, Zhuang YY, Dai SG, Li TL (2003). Isolation and identification of extracts of Eichhornia crassipes and their allelopathic effects on algae. Bulletin of Environmental Contamination and Toxicology 71(5):1048-1052.

Jinhu M, Guofang X, Wenxiu Y, Leilei M, Mei G, Yugu W, Yuanhuai $H$ (2012). Inhibitory effects of leachate from Eupatorium adenophorum on germination and growth of Amaranthus retroflexus and Chenopodium glaucum. Acta Ecologica Sinica 32(1):50-56.

Johani NSA, Aytah AA, Boutraa T (2012). Allelopathic impact of two weeds, Chenopodium murale and Malva parviflora on growth and photosynthesis of barley (Hordeum vulgare L.). Pakistan Journal of Botany 44(6):1865-1872.

Kapoor RT (2012). Phytotoxic potential of fresh leaf leachates and dry leaf extracts of Hyptis suaveolens to control Parthenium hysterophorus L. International Conference on Chemical Processes and Environmental issues, Singapore pp 154-158.

Katoch R, Singh A, Thakur N (2012). Effect of weed residues on the physiology of common cereal crops. International Journal of Engineering Research and Applications 2(5):828-834.

Kavitha D, Arumugam K (2012). Allelopathic potential of Cynodon dactylon (L.) Pers. and Ammania baccifera L. on growth and biochemical changes of black gram (Vigna mungo (L.) Hepper.). Plant Archives 12:891-897.

Khan B, Jama M, Azim H (2004). Effect of weeds on cane yield and content of sugarcane. Pakistan Journal of Weed Science Research 10(1):47-50.

Khan R, Khan MA, Waqas M, Haroon M, Hussain Z, Khan N,...Bashir $S$ (2012). Bioherbicidal activity of some winter weeds against some crops. Pakistan Journal of Weed Science Research 18(4):561-569.

Khanh TD, Xuan TD, Chung IM, Tawata S (2008). Allelochemicals of barnyard grass infested soil and their activities on crops and weeds. Weed Biology and Management 8(4):267-275.

Komai K, Ueki K (1975). Chemical properties and behavior of polyphenolic substances in purple nutsedge (Cyperus rotundus L.).Weed Research 20:66-71.

Kruse M, Strandberg M, Strandberg B (2000). Ecological effects of allelopathic plants - A review. National environmental research institute - NERI technical report No 315. Silkeborg, Denmark.

Lin PS, Jun W, Feng GQ (2004). Mechanism and active variety of allelochemicals. Acta Botanica Sinica 46(7):757-766.

Majeed A, Chaudhry Z, Muhammad Z (2012). Allelopathic assessment of fresh aqueous extracts of Chenopodium album $\mathrm{L}$. for growth and yield of wheat (Triticum aestivum L.). Pakistan Journal of Botany $44(1): 165-167$. 
Mallik MAB, Puchala R, Grosz FA (1994). A growth-inhibitory factor from lambsquarters (Chenopodium album). Journal of Chemical Ecology 20(4):957-967.

Mandal S (2001). Allelopathic activity of root exudates from Leonurus sibiricus L. (Raktodrone). Weed Biology and Management 1(3):170-175.

Marwat KB, Saeed M, Hussain Z, Gul B, Rashid H (2008). Study of various herbicides for weed control in wheat under irrigated conditions. Pakistan Journal of Weed Science Research $14(1 / 2): 1-8$.

Matloob A, Khaliq A, Farooq M, Cheema ZA (2010). Quantification of allelopathic potential of different crop residues for the purple nutsedge suppression. Pakistan Journal of Weed Science Research 16(1):1-12.

Mehmood A, Tanveer A, Nadeem MA, Zahir ZA (2014). Comparative allelopathic potential of metabolites of two Alternanthera species against germination and seedling growth of rice. Planta Daninha 32(1):1-10.

Mohadesi A, Abbasian A, Bakhshipour S, Tavasoli F, Salehi MM, Madani A (2011). Allelopathy of weed extracts on yield and its components in four cultivars of rice (Oryza sativa L.). Journal of Central European Agriculture 12(1):70-80.

Molisch H (1937). Der Einfluss einer Pflanze auf die andere Allelopathie. Fischer, Jena, Germany.

Muscolo A, Panuccio MR, Sidari M (2001). The effects of phenols on respiratory enzymes in seed germination. Plant Growth Regulation 35(1):31-35.

Muzaffar S, Ali B, Wani NA (2012). Effect of catechol, gallic acid and pyrogallic acid on the germination, seedling growth and the level of endogenous phenolics in cucumber (Cucumis sativus L.). International Journal of Life Science, Biotechnology and Pharmacology Research 1(3):50-55.

Namdari T, Amini R, Sanayei S, Kia SA, Nasab ADM (2012). Allelopathic effects of redroot pigweed (Amaranthus retroflexus L.) root exudates on common bean seedling growth. International Research Journal of Applied and Basic Sciences 3:1230-1234.

Narwal SS (2004). Allelopathy in crop production. Scientific Publishers, Jodhpur, India.

Narwal SS, Palaniraj R, Sati SC (2005). Role of allelopathy in crop production. Herbologia 6(1):4-23.

Noguchi HK (2008). Allelochemicals released from rice plants. Japanese Journal of Plant Sciences 2:18-25.

Obaid KA, Qasem JR (2005). Phytotoxicity of some common weed species to certain vegetable crops grown in Jordan. Dirasat, Agricultural Sciences 32(1):10-20.

Oerke EC, Dehne HW (2004). Safeguarding production losses in major crops and the role of crop protection. Crop Protection 23(4):275-285.

Omezzine F, Rinez A, Ladhari A, Farooq M, Haouala R (2011). Allelopathic potential of Inula viscosa against crops and weeds. International Journal of Agriculture and Biology 13(6):841-849.

Otusanya OO, Ikonoh OW, Ilori OJ (2008). Allelopathic potential of Tithonia diversifolia (Hemsl) and effect on the germination, growth and chlorophyll accumulation of Capsicum annum $\mathrm{L}$.
International Journal of Botany 4(4):471-475.

Qasem JR (2001). Allelopathic potential of white top and Syrian sage on vegetable crops. Agronomy Journal 93(1):64-71.

Qureshi ZM, Hussain F, Shaukat S (1987). Allelopathic effect of Avena fatua Linn. on some crops. In: Modern trend of plant science research in Pakistan. Proceedings of the Third National Conference of Plant Scientists. Peshawar, Department of Botany, University of Peshawar pp 53-58.

Randhawa MA, Al-Ghamdi MS (2002). A review of the pharmacotherapeutic effects of Nigella sativa. Pakistan Journal of Medical Research 41(2):77-83.

Rahman A (2005). Allelopathic potential of Parthenium bysterophorus on seed germination, growth and dry matter production in Cassia tora. Journal of Ecotoxicology and Environmental Monitoring 15(4):381-386.

Rodzynkiewicz ES, Dabkowska T, Stoklosa A, Hura T, Dubert F, Lepiarczyk A (2006). The effect of selected phenolic compounds on the initial growth of four weed species. Journal of Plant Diseases and Protection 20:479-486.

Samad MA, Rahman MM, Hossain AKMM, Rahman MS, Rahman SM (2008). Allelopathic effects of five selected weed species on seed germination and seedling growth of corn. Journal of Soil Nature 2(2):13-18.

Sasikumar K, Parthiban KT, Kalaiselvi T, Jagatram M (2002). Allelopathic effects of Parthenium hysterophorus on cowpea, pigeonpea, greengram, blackgram and horsegram. Allelopathy Journal 10(1):45-52.

Sayed MA, Haque MM, Roy B, Hossain SMJ, Das SR (2012). Allelopathic effects of different extracts of honeyweed (Leonurus siribicus) on seeds germination and seedlings growth of some selected vegetables. Journal of Natural Products 5:243-250.

Schumacher WJ, Thill DC, Lee GA (1983). Allelopathic potential of wild oat (Avena fatua) on spring wheat (Triticum aestivum) growth. Journal of Chemical Ecology 9(8):1235-1246.

Scrivanti LR (2010). Allelopathic potential of Bothriochloa laguroides var. laguroides (DC.) Herter (Poaceae, Andropogoneae). FloraMorphology, Distribution, Functional Ecology of Plants 205(5):302-305.

Senarathne SHS, Dissanayaka DNM, Arachchi LPV (2010). Allelopathic potential of Brachiaria brizantha and B. milliformis on seed germination of selected bioassay species. Pakistan Journal of Weed Science Research 16(2):207-216.

Shao H, Peng S, Wei X, Zhang D, Zhang C (2005). Potential allelochemicals from an invasive weed Mikania micrantha H.B.K. Journal of Chemical Ecology 31(7):1657-1668.

Shao-Lin P, Jun W, Qin-Feng G (2004). Mechanism and active variety of allelochemicals. Acta Botanica Sinica 46(7):757-766.

Shaukat SS, Munir N, Siddiqui IA (2003). Allelopathic responses of Conyza canadensis (L.) Cronquist, a cosmopolitan weed. Asian Journal of Plant Science 2(14):1034-1039.

Siddiqui S, Bhardwaj S, Khan SS, Meghvanshi MK (2009). Allelopathic effect of different concentration of water extract of Prosopsis Juliflora leaf on seed germination and radicle length of 
wheat (Triticum aestivum Var-Lok-1). American-Eurasian Journal of Scientific Research 4(2):81-84.

Singh HP, Batish DR, Kohli RK (2001). Allelopathy in agroecosystems, an overview. Journal of Crop Production 4(2):141.

Singh HP, Batish DR, Pandher JK, Kohli RK (2005). Phytotoxic effects of Parthenium hysterophorus residues on three Brassica species. Weed Biology and Management 5(3):105-109.

Sultana S, Asaduzzaman M (2012). Allelopathic studies on milk thistle (Silybum marianum). International Journal of Agricultural Research, Innovation and Technology 2(1):62-67.

Swain D, Paroha S, Singh M, Subudhi HN (2012). Evaluations of allelopathic effect of Echinochloa colona weed on rice (Oryza sativa L. 'Vandana'). Journal of Environmental Biology 33(5):881-889.

Tames RS, Gesto MDV, Vieitez E (1973). Growth substances isolated from tubers of Cyperus esculentus var. aureus. Physiologia Plantarum 28(2):195-200.

Tanveer A, Khaliq A, Ali HH, Mahajan G, Chauhan BS (2015). Interference and management of Parthenium, the world's most important invasive weed. Crop Protection 68:49-59.

Tanveer A, Rehman A, Javaid MM, Abbas RN, Sibtain M, Ahmad AH, ... Aziz A (2010). Allelopathic potential of Euphorbia helioscopia L. against wheat (Triticum aestivum L.), chickpea (Cicer arietinum L.) and lentil (Lens culinaris Medic.). Turkish Journal of Agriculture and Forestry 34(1):75-81.

Torres A, Oliva RM, Castellano D, Cross P (1996). First world congress on allelopathy-a science of the future. Cadiz, Spain.

Verma M, Rao PB (2006). Allelopathic effect of four weed species extracts on germination, growth and protein in different varieties of Glycine max (L.) Merrill. Journal of Environmental Biology 27(3):571-577.
Wakjira M, Berecha G, Tulu S (2009). Allelopathic effects of an invasive alien weed Parthenium hysterophorus L. compost on lettuce germination and growth. African Journal of Agricultural Research 4(11):1325-1330.

WangJC, Wu Y, Wang Q, Peng YL, Pan KW, Luo P, Wu N (2009). Allelopathic effects of Jatropha curcas on marigold (Tagetes erecta L.). Allelopathy Journal 24:123-130.

White RH, Worsham AD, Blum O (1989). Allelopathic potential of legume debris and aqueous extracts. Weed Science 37:674-679.

Willis RJ (1985). The historical bases of the concept of allelopathy. Journal of the History of Biology 18(1):71-102.

Yan Z, Guo H, Yang J, Liu Q, Jin H, Xu R, Cuia H, Qin B (2014). Phytotoxic flavonoids from roots of Stellera chamaejasme L. (Thymelaeaceae). Phytochemistry 106:61-68.

Yasin M, Safdar ME, Iqbal Z, Ali A, Jabran K, Tanveer A (2012). Phytotoxic effects of Calotropis procera extract on germination and seedling vigour of wheat. Pakistan Journal of Weed Science Research 18(3):379-392.

Yukiko I, Yasuo K, Minoru T (2001). Effects of phenolic compounds on seed germination of shirakamba birch, Betula platyphylla var. japonica. Eurasian Journal of Forest Research 2(1):17-25.

Zohaib A, Ehsanullah, Tabassum T, Abbas T, Rasool T (2014). Influence of water soluble phenolics of Vicia sativa $\mathrm{L}$. on germination and seedling growth of pulse crops. Scientia Agriculture 8(3):148-151.

Zohaib A, Tanveer A, Khaliq A, Safdar ME (2014). Phytotoxic effect of water soluble phenolics from five leguminous weeds on germination and seedling growth of rice. Pakistan Journal of Weed Science Research 20(4):417-429. 